PNL-SA-24841

\title{
SOLID-STATE SINTERING OF TUNGSTEN HEAVY ALLOYS
}

W. E. Gurwell

October 1994

Presented at the

1994 International Conference on Tungsten \& Refractory

Metals

October 17-19, 1994

McClean, Virginia

Prepared for

the U.S. Department of Energy

under Contract DE-AC06-76RLO 1830

Pacific Northwest Laboratory

Richland, Washington 99352 


\section{DISCLAIMER}

Portions of this document may be illegible in electronic image products. Images are produced from the best available original document. 


\title{
SOLID-STATE SINTERING OF TUNGSTEN HEAVY ALLOYS
}

\author{
W. E. Gurwell \\ Pacific Northwest Laboratory ${ }^{\text {(a) }}$ \\ Richland, Washington 99352
}

\begin{abstract}
Solid-state sintering is a technologically important step in the fabrication of tungsten heavy alloys. This work addresses practical variables affecting the sinterability: powder particle size, powder mixing, and sintering temperature and time. Compositions containing 1 to 10 micrometer $(\mu \mathrm{m})$ tungsten (W) powders can be fully densified at temperatures near the matrix solidus. Blending with an intensifier bar provided good dispersion of elemental powders and good as-sintered mechanical properties under adequate sintering conditions. Additional ball milling increases powder bulk density which primarily benefits mold and die filling. Although fine, $1 \mu \mathrm{m} \mathrm{W}$ powder blends have high sinterability, higher as-sintered ductilities are reached in shorter sintering times with coarser, $5 \mu \mathrm{m} \mathrm{W}$ powder blends; $10 \mu \mathrm{m} \mathrm{W}$ powder blends promise the highest as-sintered ductilities due to their coarse microstructural W.
\end{abstract}

\section{INTRODUCTION}

Tungsten heavy alloys are pressed and sintered from elemental powders of $\mathrm{W}$, nickel (Ni), iron $(\mathrm{Fe})$, and/or cobalt $(\mathrm{Co})$, and sometimes copper ( $\mathrm{Cu})$. Alloys of $>85 \% \mathrm{~W}$ can be liquid-phase (LP) sintered to high densities but with some slumping and loss of shape that diminishes as the W content increases. The slumping can be controlled by first solid-state (SS) sintering to full density and potting the part in refractory "sand" before the LP sintering. Alloys $<85 \% \mathrm{~W}$ must be SS sintered to avoid "settling" of the W phase ${ }^{(1)}$ as well as severe slumping; such low W alloys can be worked and SS annealed into materials having the consistently high ductilities and strengths typical for a wrought material. (2) For these reasons the SS sintering of the full range of W heavy alloys to full, $100 \%$, densities is of interest.

(a) Operated by Battelle Memorial Institute for the U.S. Department of Energy. 
This work addresses some of the primary variables affecting SS sintering: W powder particle size and powder mixing; sintering data were developed for alloys of $40 \%, 70 \%, 80 \%$, and $90 \% \mathrm{~W}$, alloyed with either $\mathrm{Ni}-\mathrm{Fe}$ or $\mathrm{Ni}-\mathrm{Co}$. Tungsten powders used were limited to some of those commercially available and do not include specially prepared, sub-micron powders such as freeze-dried powders $^{(3)}$ which are highly sinterable, sintering to full density several hundred degrees Celsius below the matrix melting temperature, $1460^{\circ} \mathrm{C}$. Nickel, Fe, and $\mathrm{Co}$ elemental alloying additions activate the SS sintering of W powders to high densities, ${ }^{(4)}$ sintering being further enhanced by smaller W particle sizes. ${ }^{(5)}$ However, the highest ductilities and lowest hardnesses are obtained from larger as-sintered $\mathrm{W}$ particle sizes in both LP sintering ${ }^{(6)}$ and in SS sintering; ${ }^{(2)}$ for this reason, the sinterability of powder mixes using $10 \mu \mathrm{m} \mathrm{W}$ powders is investigated in addition to the typical 1 and $5 \mu \mathrm{m} W$ powders.

\section{EXPERIMENTAL PROCEDURES}

The characteristics of the powders used are listed in Table 1. The $W$ particle sizes measured after laboratory milling (listed in parentheses) are thought to most closely represent the true, deagglomerated $\mathrm{W}$ particle size (the $\mathrm{W}$ powder agglomerates are -200 mesh, and the $\mathrm{Fe}, \mathrm{Ni}$, and Co agglomerates are $-300 \mathrm{mesh}$ ). The weighed elemental powders mixtures were blended in a twin-shell blender for $30 \mathrm{~min}$ with the intensifier bar running $1 \mathrm{~min}$ of every $5 \mathrm{~min}$.

Table 1. Powder Characteristics

\begin{tabular}{|c|c|c|c|c|c|}
\hline Powder & Source/Grade & $\begin{array}{c}\text { Particle Size, } \\
\mu \mathrm{m}^{(\mathrm{a})}\end{array}$ & $\begin{array}{l}\text { Apparent Density, } \\
\mathrm{g} / \mathrm{cm}^{3(\mathrm{~b})}\end{array}$ & C, ppm & $\mathrm{O}, \mathrm{ppm}$ \\
\hline $1-\mu \mathrm{m} \mathrm{W}$ & $\begin{array}{l}\text { Teledyne Wah } \\
\text { Chang/C5 }\end{array}$ & $1.12(1.00)$ & 2.01 . & 32 & 880 \\
\hline $5-\mu \mathrm{mW}$ & $\begin{array}{c}\text { Teledyne Wah } \\
\text { Chang/C10 }\end{array}$ & $4.60(3.68)$ & 3.57 & 8 & 160 \\
\hline $10-\mu \mathrm{m} \mathrm{W}$ & $\begin{array}{c}\text { Teledyne Wah } \\
\text { Chang/C40 }\end{array}$ & $13.00(10.00)$ & 3.75 & 1 & 100 \\
\hline $\mathrm{Ni}$ & INCO 123 & 4.07 & 1.93 & 650 & 610 \\
\hline $\mathrm{Fe}$ & GAF HP & 6-8 typ. & $1.9 \max$ & 1000 & $3000 \max$ \\
\hline $\mathrm{Fe}$ & BASF CM & 6.2 & - & 200 & 2000 \\
\hline Co & Carolment EF & 1.39 & 1.02 & $300 \max$ & 5300 \\
\hline
\end{tabular}

(a) Fisher subsieve size, American Society for Testing and Materials (ASTM) B330. Particle size in parentheses taken after lab milling.

(b) Scott Volumeter, ASTM B329.

Except where noted the blended powders were dry ball milled for 16 hours to break up agglomerates, provide intimate mixing, and uniformly disperse the elemental powders. The milling was done in 1 gallon, rubber-lined jars using typical dry grinding parameters: jar half filled with 1/2-in. diameter, 440 stainless steel balls, powder volume equal to $1 / 4$ the mill volume, and mill speed equal to $65 \%$ of the critical speed $(62 \mathrm{rpm})$. 
The milled powders were either isostatically pressed at 27 kips per square in. (ksi) (without lubricant) or uniaxially pressed at $40 \mathrm{ksi}$ with lithium stearate die-wall lubricant, and sintered in a cold-wall furnace with $100 \%$ hydrogen atmosphere (typical dew points of $-20^{\circ} \mathrm{C}$ ). Typical heating rates were $500^{\circ} \mathrm{C} / \mathrm{h}$, and included a 1 -hour hold at $900^{\circ} \mathrm{C}$ and a 1 -hour ramp to $1100^{\circ} \mathrm{C}$ during heating for oxide reduction.

Green densities were measured from dimensions and mass. As-sintered immersion densities were measured according to ASTM B311.. Tensile tests, according to ASTM E8, were run at $0.01 \mathrm{in} . / \mathrm{min}$ to the yield point and then $0.05 \mathrm{in} . / \mathrm{min}$ to failure. Tensile bars were either MPIF standard powder bars or they were machined from as-sintered slabs to ASTM E-8 dimensions.

\section{EFFECTS OF BALL MILLING}

Three alloys were studied: 1) $40 \% \mathrm{~W}(1 \mu \mathrm{m})$ with $\mathrm{Ni} / \mathrm{Fe}$ ratio of $8 / 2$ (using the BASF CM Fe), 2) $70 \% \mathrm{~W}(5 \mu \mathrm{m})$ with Ni/Co ratio of $2 / 1$, and 3) $80 \% \mathrm{~W}(5 \mu \mathrm{m})$ with Ni/Co ratio of $2 / 1$. The starting ball mill powder loadings for equal volumes were dependent on the calculated bulk density of the elemental powder alloy mixes and were $4400 \mathrm{~g}, 5000 \mathrm{~g}$, and $5500 \mathrm{~g}$, respectively. As-blended powders were ball milled as described previously and $100 \mathrm{~g}$ samples of powder were withdrawn periodically to follow the progress of milling induced changes in powder density and sinterability.

For each $100 \mathrm{~g}$ sample the "pour density" was measured by gently spooning the $100 \mathrm{~g}$ sample into a 100 graduated cylinder, and the "tap density" was measured after vibrating the loaded graduated cylinder for $3 \mathrm{~min}$ on an oscillating drum packer. Cylindrical pellets, 0.45 -in. diameter by 0.45 in. long, were uniaxially pressed at 40 -ksi and sintered at $1425^{\circ} \mathrm{C}$ for either 1 or 3 hours.

The effects of ball milling time are shown in Figure 1, where densities are plotted as percent of theoretical (11.1, 14.1, and $15.5 \mathrm{~g} / \mathrm{cc}$ for the $40 \% \mathrm{~W}, 70 \% \mathrm{~W}$, and $80 \% \mathrm{~W}$ alloys, respectively). There is a remarkable similarity in behavior for all three alloys despite the wide variation in W content and the $\mathrm{Fe}$ and $\mathrm{Co}$ alloying elements. As shown in Figure 1, the "pour" and "tap" densities were significantly increased during the first 3 hours of milling, which certainly benefits mold or die filling. Conversely, green strength (qualitatively measured by hand on $1 / 8$-in.-thick uniaxially pressed pellets) decreased continuously with milling time (i.e., the edges chipped easier and the bend strength fell with time). Although green densities are not strongly affected by milling, short-time, 1 hour, as-sintered densities are improved significantly, climbing from near $93 \%$ to $96 \%$ with 15 hours of milling.

However, with longer ( 3 hours) sintering time, density increases for all milling times, and the range is much narrower, between approximately $97.5 \%$ and $99 \%$.

Except for a drop in porosity as density increased, there was little microstructural change in the sintered samples with milling time; very little change in the degree of $W$ dispersion or in $W$ particle size was observable after sintering. Milling did not influence the tensile properties of MPIF bars sintered for 3 hours, as shown in Table 2; in fact, the tensile properties of both the $70 \% \mathrm{~W}$ and $80 \% \mathrm{~W}$ alloys from unmilled powders are adequate for subsequent hot working. At the longer milling times the MPIF tensile bar pressings cracked and laminated during pressing, again indicating lowered, and for these uniaxial pressings, inadequate green strength; isostatic pressings, however, could be made from even the longest-milled powders.

\section{EFFECTS OF W PARTICLE SIZE}

Since $W$ powder is a large fraction of most $W$ heavy alloys, the $W$ particle size has a controlling influence on sinterability, as well as as-sintered mechanical properties. These effects were investigated 


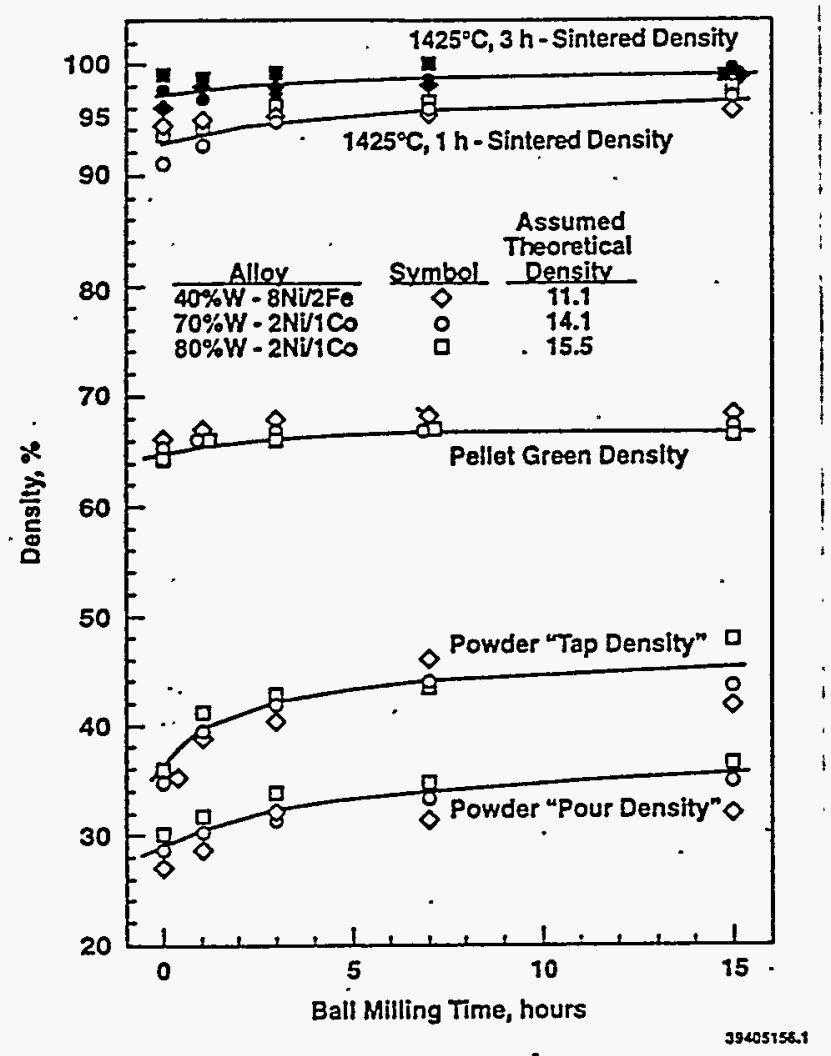

Figure 1. Effect of ball milling time on powder and pellet densities for $40 \% \mathrm{~W}, 70 \% \mathrm{~W}$, and $80 \% \mathrm{~W}$ alloys.

Table 2. Influence of Ball Milling Time on As-Sintered Tensile Properties of $70 \% \mathrm{~W}$ and $80 \% \mathrm{~W}$ Alloys (alloyed with $2 \mathrm{Ni} / 1 \mathrm{Co}$ and sintered 3 hours at $1425^{\circ} \mathrm{C}$ )

\begin{tabular}{|c|c|c|c|c|}
\hline Milling Time $-\mathrm{h}$ & Density - $g / c c$ & Yield Strength - ksi & $\begin{array}{c}\text { Ultimate } \\
\text { Strength - ksi }\end{array}$ & Elongation - \% \\
\hline \multicolumn{5}{|l|}{$70 \% \mathrm{~W}$} \\
\hline 0 (as-blended) & 13.83 & 78 & 151 & 33 \\
\hline 1 & $14.00(14.1)$ & 80 & 160 & 32 \\
\hline 3 & 14.10 & 85 & 163 & 35 \\
\hline 7 & - & & & \\
\hline 15 & \multicolumn{4}{|c|}{ cracked or laminated during pressing at $40 \mathrm{ksi}$} \\
\hline \multicolumn{5}{|l|}{$\underline{80 \% \mathrm{~W}}$} \\
\hline 0 & 15.36 & 89 & 155 & 20 \\
\hline 1 & $15.49(15.5)$ & 92 & 158 & 20 \\
\hline 3 & 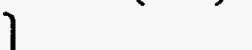 & & & \\
\hline 7 & \multirow{2}{*}{\multicolumn{4}{|c|}{ cracked or laminated during pressing at $40 \mathrm{ksi}$}} \\
\hline 15 & & & & \\
\hline
\end{tabular}


using powder mixtutes made from 1,5 , and $10 \mu \mathrm{m} W$ powders (Table 1) that were milled, isopressed, and sintered in hydrogen according to the procedures described earlier. The most complete data were developed for the $70 \% \mathrm{~W}$ alloy; complementary data for $80 \% \mathrm{~W}$ and $90 \% \mathrm{~W}$ alloys are also presented.

The sinterabilities of $70 \% \mathrm{~W}$ alloys using 1 and $5 \mu \mathrm{m}$ powders is illustrated in Figure 2 . The high sinterability of powder mixtures containing $1 \mu \mathrm{m} \mathrm{W}$ is readily apparent; high densities are reached at relatively low temperatures and short times. As sintering time and temperature increase, hardness falls (Figure 2) as the W particles coarsen (Figure 3). For the less sinterable $5 \mu \mathrm{m} \mathrm{W}$ powder mix, hardness increases continuously with density, full densification being attained above 1 hour and $1400^{\circ} \mathrm{C}$.

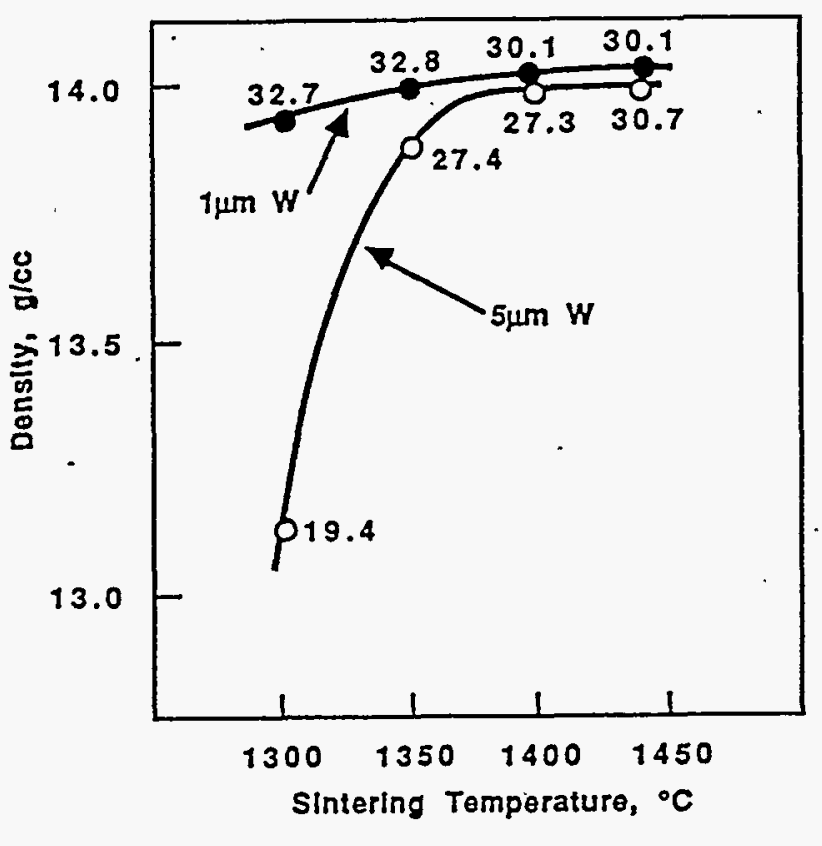

Figure 2. Sintered Density of $70 \% \mathrm{~W}$ Alloy as a Function of Sintering Temperature ( 1 hour at temperature) and W Powder Size (as-sintered hardness, HRC, indicated at each data point)

Tensile properties for fully densified, $14.0 \mathrm{~g} / \mathrm{cc}, 70 \% \mathrm{~W}$ alloys are given in Table 3; although the hardness of all specimens was HRC (Rockwell "C" hardness) $30 \pm 1$, there are significant-differences in yield strength and elongation which are related to microstructural $W$ particle size. After 1 hour at $1400^{\circ} \mathrm{C}$ the $1 \mu \mathrm{m} \mathrm{W}$ mix is fully densified, but has relatively high yield strength and low elongation, which is due to the microstructural fineness, shown in Figure $3 \mathrm{a}$. In contrast, $5 \mu \mathrm{m} \mathrm{W} \mathrm{mix}$ reaches a ductile state of high elongation combined with low yield strength after only 1 hour at $1440^{\circ} \mathrm{C} ; 4$ hours at $1440^{\circ} \mathrm{C}$ are required for the $1 \mu \mathrm{m} \mathrm{W}$ mix to approach the same properties, and similar $\mathrm{W}$ microstructure as shown in Figures $3 \mathrm{c}$ and $3 \mathrm{~d}$. The slightly lower ductility for the $1 \mu \mathrm{m} \mathrm{W}$ $\operatorname{mix}\left(\right.$ after $4 \mathrm{~h}-1440^{\circ} \mathrm{C}$ ) relative to the $5 \mu \mathrm{m}$ mix (after $1 \mathrm{~h}-1440^{\circ} \mathrm{C}$ ) with similar $\mathrm{W}$ particle size may be due to higher carbon content in the $1 \mu \mathrm{m} \mathrm{W}$ powder (Table 1). (As-sintered oxygen contents were similar for both $1 \mu \mathrm{m} \mathrm{W}$ and $5 \mu \mathrm{m} \mathrm{W}$ mixes, ranging from 8 to $12 \mathrm{ppm}$.) The one necessary conclusion from this information is that while finer $\mathrm{W}$ mixes are more sinterable, longer sintering times are required to reach maximal ductilities, which are slightly lower than that obtainable from a coarser W powder mix. Therefore, the optimal choice is the coarsest $\mathrm{W}$ powder mix that will sinter to full density in a reasonably short time, say 1 to 3 hours. 


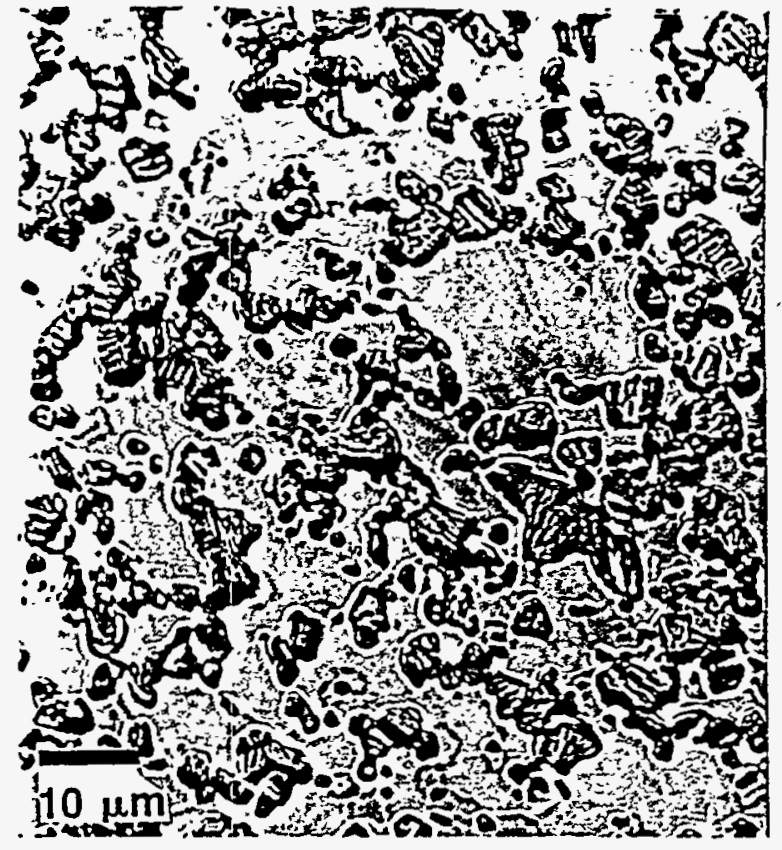

(a) $1 \mu \mathrm{m} \mathrm{W}, 1 \mathrm{~h}-1400^{\circ} \mathrm{C}$

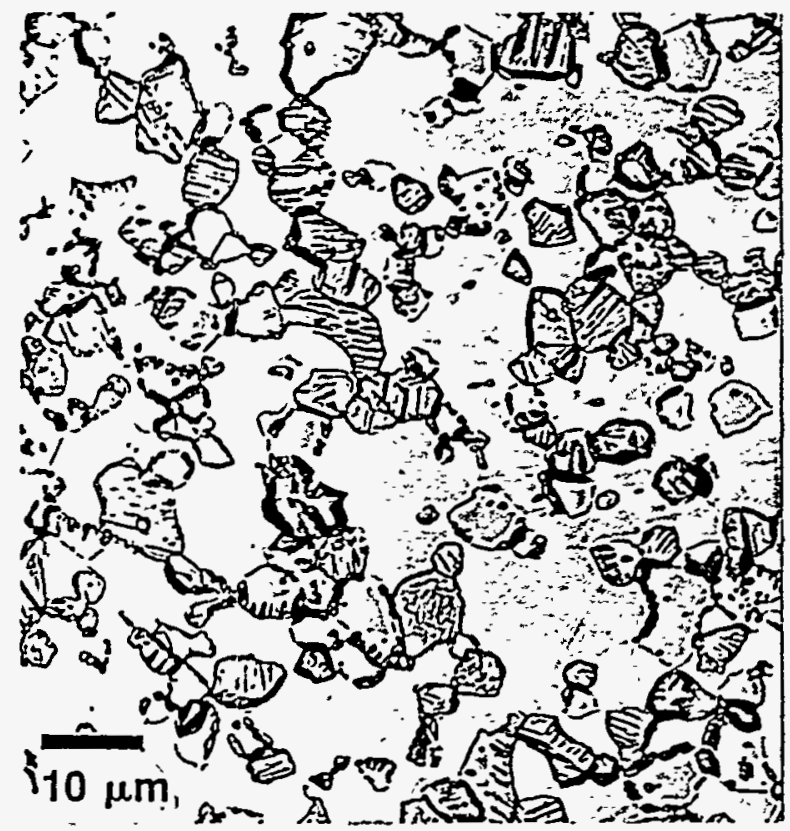

(c) $1 \mu \mathrm{m} \mathrm{W}, 4 \mathrm{~h}-1400^{\circ} \mathrm{C}$

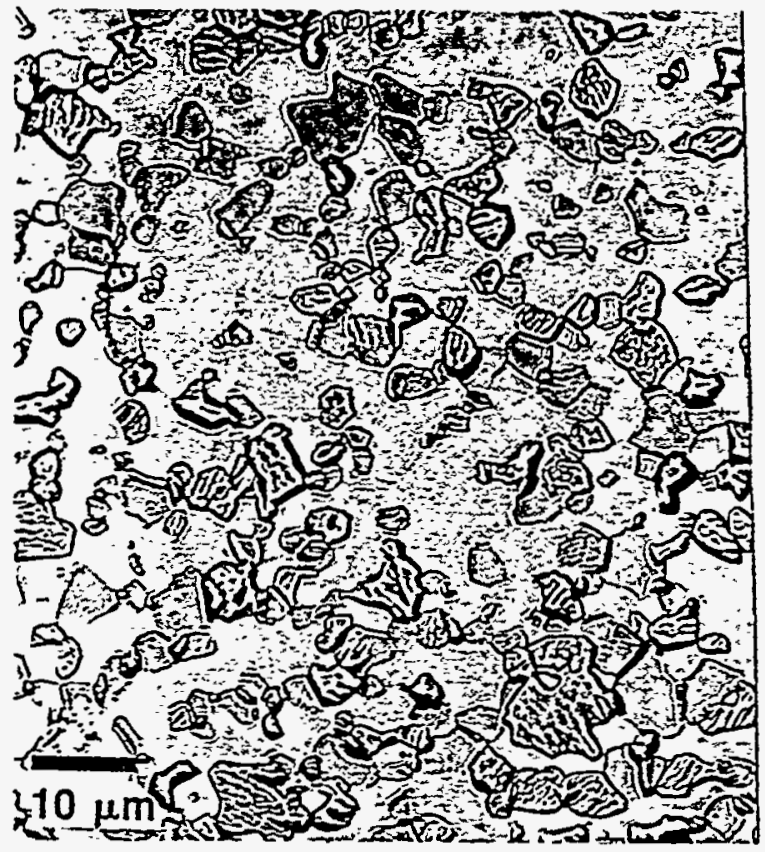

(b) $1 \mu \mathrm{m} \mathrm{W}, 1 \mathrm{~h}-1440^{\circ} \mathrm{C}$

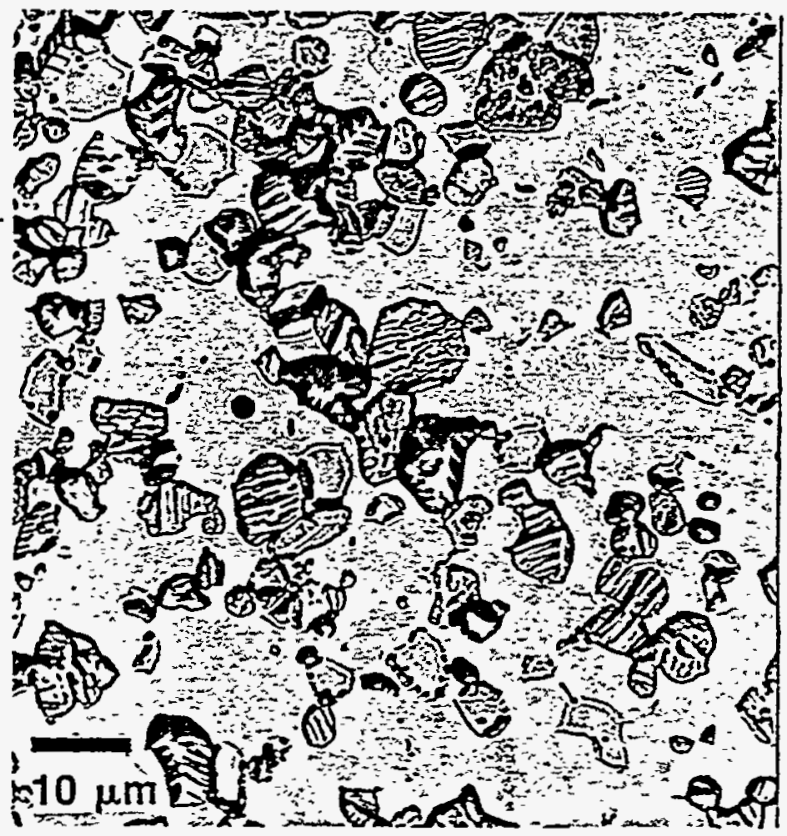

(d) $5 \mu \mathrm{m} \mathrm{W}, 1 \mathrm{~h}-1440^{\circ} \mathrm{C}$

Figure 3. As-sintered $70 \% \mathrm{~W}$ microstructures. (Note definite coarsening of the $1 \mu \mathrm{m} \mathrm{W}$ powder billets with increasing temperature and time: $a, b$, and $c$. Compare (b) and (c) with $5 \mu \mathrm{m} \mathrm{W}$ powder billet (d) after sintering at $1440^{\circ} \mathrm{C}$ for 1 hour.) 
Table 3. Sintered Properties of 70\% W Alloys from 1 and $5 \mu \mathrm{m} W$

\begin{tabular}{ccccc}
\hline Sinter Cycle ${ }^{(a)}$ & W Size $\mu$ & Yield ksi & Ultimate ksi & Elongation \% \\
\hline $1400^{\circ} \mathrm{C}-1 \mathrm{~h}$ & 1 & 93 & 146 & 20 \\
$1440^{\circ} \mathrm{C}-1 \mathrm{~h}$ & 1 & 87 & 146 & 25 \\
& 5 & 81 & 141 & 38 \\
$1440^{\circ} \mathrm{C}-4 \mathrm{~h}$ & 1 & 81 & 144 & 30 \\
& 5 & 80 & 142 & 34 \\
$1440^{\circ} \mathrm{C}-6 \mathrm{~h}$ & 1 & 82 & 143 & 30 \\
& 5 & 79 & 140 & 34
\end{tabular}

(a) Vacuum degassed $30 \mathrm{~min}$ at $1000^{\circ} \mathrm{C}$ after sintering and machining into 0.17 -in.-thick tensile bars. Sintered density of all specimens was $14.0 \mathrm{~g} / \mathrm{cc}$.

Alloys of $80 \% \mathrm{~W}$ and $90 \% \mathrm{~W}$ have sinterabilities, similar to the $70 \% \mathrm{~W}$ alloys, as shown in Figure 4. With $5 \mu \mathrm{m} \mathrm{W}$ powder mixes, high densities are reached in a few hours; Figure 5 contains typical microstructures.

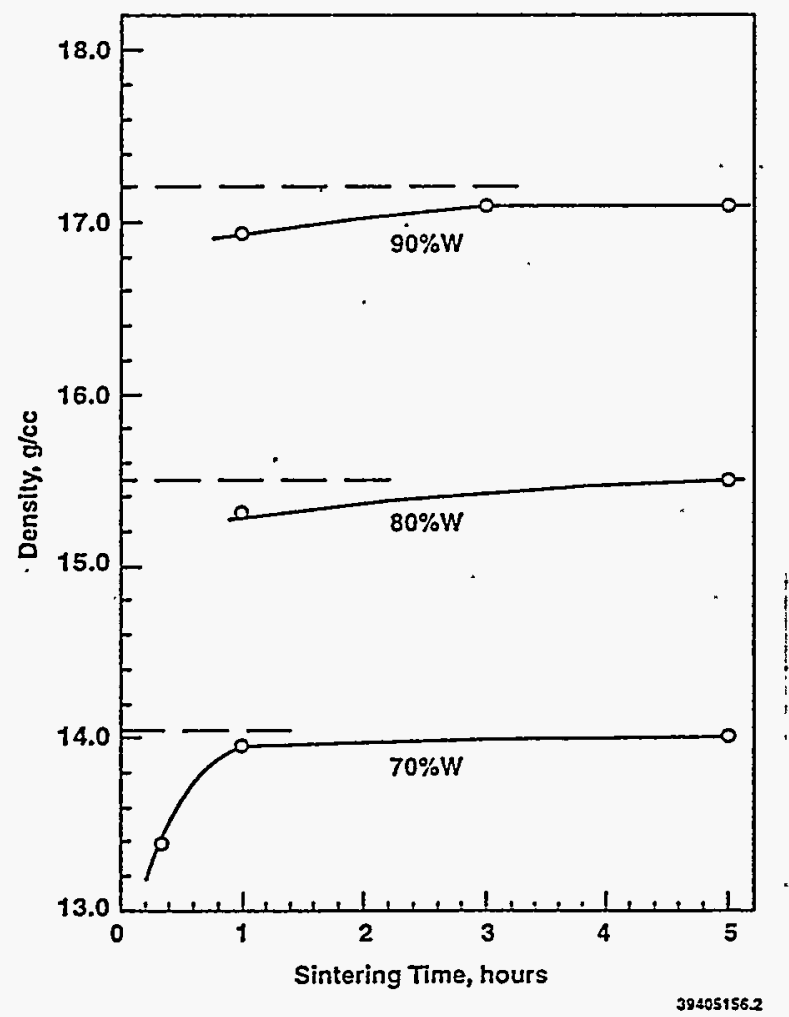

Figure 4. Sintering curves for alloy powders made with $5 \mu \mathrm{m} \mathrm{W}$. (Dashed lines indicate $100 \%$ densities. $90 \% \mathrm{~W}: 8 \mathrm{Ni} / 2 \mathrm{Fe}$ at $1425^{\circ} \mathrm{C} ; 80 \% \mathrm{~W}: 8 \mathrm{Ni} / 2 \mathrm{Fe}$ at $1425^{\circ} \mathrm{C} ; 70 \% \mathrm{~W}: 7 \mathrm{Ni} / 3 \mathrm{Fe}$ at $1400^{\circ} \mathrm{C}$.) 

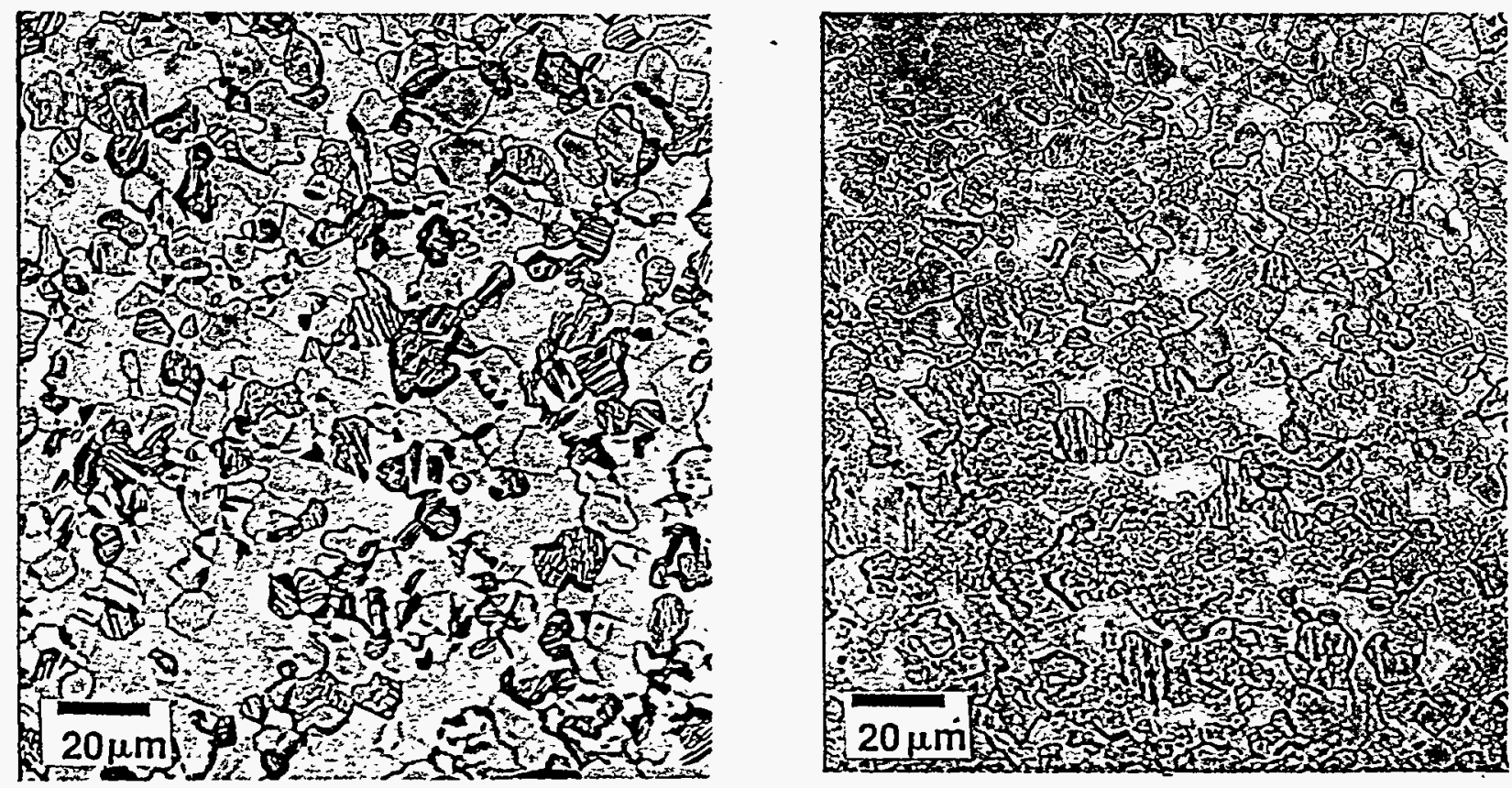

Figure 5. As-sintered microstructures of $80 \% \mathrm{~W}$ (left) and $90 \% \mathrm{~W}$ (right) alloys from $5 \mu \mathrm{m} \mathrm{W}$ Powder (sintered 5 hours at $1425^{\circ} \mathrm{C}$ ).

Based on the conclusion that the coarsest $\mathrm{W}$ powder mix will yield optimum as-sintered ductiles, the sinterability of coarse, $10 \mu \mathrm{m} \mathrm{W}$ powder mixes was investigated for $70 \%, 80 \%$, and $90 \% \mathrm{~W}$ alloys. It was quickly learned that full densification could not be reached; some finer $\mathrm{W}$ powder had to be substituted to enhance sinterability. Addition of fine powder may compromise the expected ductility gains from $10 \mu \mathrm{m} \mathrm{W}$ powder; however if a very fine, say $1 \mu \mathrm{m}, \mathrm{W}$ is added, the compromise may be negligible for two reasons:

1. During SS sintering, $W$ coarsening occurs; that is, $W$ dissolved preferentially from the small grains is transported to the large grains by diffusion. The finer the $W$ substitution, the higher its solubility relative to the $10 \mu \mathrm{m} \mathrm{W}$ grains ${ }^{(7)}$ and therefore the higher the driving force for coarsening. Coarsening also occurs more rapidly at higher $W$ contents because the diffusion path through the matrix is shorter and there is more grain boundary contact area. ${ }^{(3)}$

2. The matrix will hold a significant amount of the $1 \mu \mathrm{m} \mathrm{W}$ in solid solution: If $30 \% \mathrm{~W}$ solubility in the matrix is assumed (typical for $\mathrm{Ni} / \mathrm{Fe}$ ratio of $8 / 2$ ), $13 \%$ of the $70 \% \mathrm{~W}$ in the $70 \% \mathrm{~W}$ alloy goes into solid solution; the amount of $\mathrm{W}$. going into solid solution decreases with total W content, to $9 \%$ in the $80 \% \mathrm{~W}$ alloy and $4.3 \%$ in the $90 \% \mathrm{~W}$ alloy.

Following this reasoning, alloys of $70 \%, 80 \%$, and $90 \% \mathrm{~W}$ were formulated with 0 to $30 \%$ of $1 \mu \mathrm{m} \mathrm{W}$ substituted for the $10 \mu \mathrm{m} \mathrm{W}$. They were milled, isopressed and sintered at $1425^{\circ} \mathrm{C}$ and $1440^{\circ} \mathrm{C}$ for 1 to 5 hours. The resulting sinterability curves are shown in Figure 6 . It is readily apparent that the higher $\mathrm{W}$ alloys require more substitution of the $1 \mu \mathrm{m} \mathrm{W}$, due to the increasing dominance of $10 \mu \mathrm{m} \mathrm{W}$ particles on sinterability relative to the finer $\mathrm{Ni}$ and $\mathrm{Fe}$. It is also apparent that the $1440^{\circ} \mathrm{C}$ sintering temperature enhances sintering markedly relative to $1425^{\circ} \mathrm{C}$; this result implies that optimal SS sintering should be done as close as possible to the matrix solidus $\left(\sim 1460^{\circ} \mathrm{C}\right)$ as practical. Skirting closely to the solidus will require accurate and uniform temperature control (burying the parts in "refractory sand" promotes temperature uniformity. within the part). Selected high 

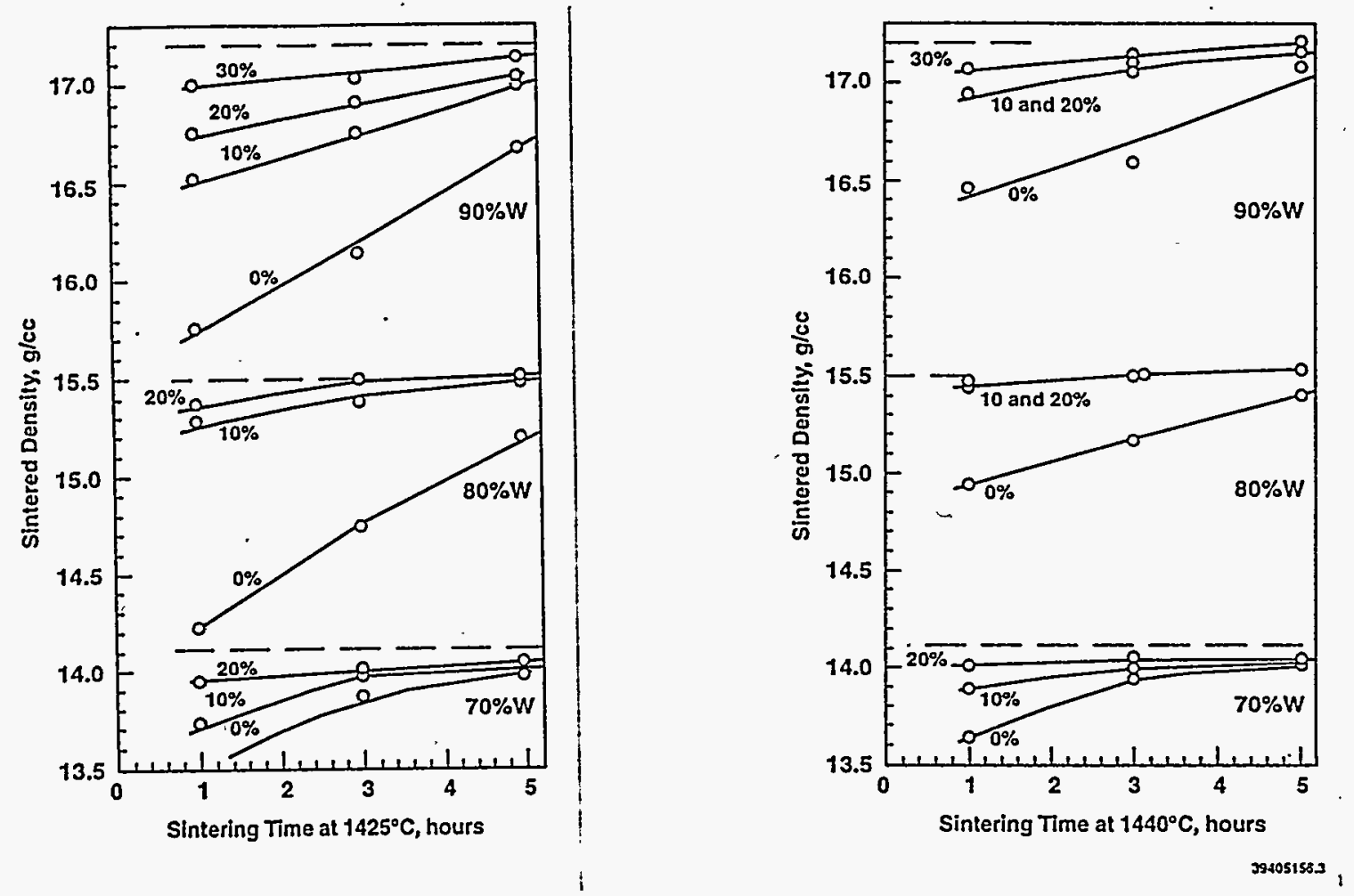

Figure 6. Sintered densities of $70 \%, 80 \%$, and $90 \% \mathrm{~W}$ alloys made with $10 \mu \mathrm{m} \mathrm{W}$ as a function of sintering time ${ }^{\circ} \mathrm{C}$ and amount of $1 \mu \mathrm{m} \mathrm{W}$ substituted for the $10 \mu \mathrm{m} \mathrm{W}$ (e.g., $90 \% \mathrm{~W}$ powder with $30 \%$ $1 \mu \mathrm{m} \mathrm{W}$ has $60 \%-10 \mu \mathrm{m} \mathrm{W}$ ). (Theoretical densities indicated by dotted line. Left: $1425^{\circ} \dot{\mathrm{C}}$ Sintering Temperature. Right: $1440^{\circ} \mathrm{C}$ Sintering Temperature.)

density microstructures of the three alloys with $10 \% 1 \mu \mathrm{m} \mathrm{W}$ substituted, Figure 7, illustrate the coarse, and potentially high ductility, microstructures available from $10 \mu \mathrm{mW}$ powders. Compare these with the microstuctures shown in Figures 3 and 5.

\section{CONCLUSIONS}

Tungsten heavy alloys can be SS sintered to full, $100 \%$ densities through the use of blended and milled powders that are conventionally pressed and sintered at sub-solidus temperature. Alloying additions of $8 \mathrm{Ni} / 2 \mathrm{Fe}, 7 \mathrm{Ni} / 3 \mathrm{Fe}$, and $2 \mathrm{Ni} / 1 \mathrm{Co}$ are equally sinterable.

Densification is sensitive to sintering temperature. There is economic incentive to crowd close to the solidus temperature to significantly reduce sintering time and thereby increase furnace throughput.

Blending with an intensifier bar provided adequate dispersion of elemental powders and good assintered tensile properties. Ball milling increased powder bulk density (which benefits mold or die filling), pressed densities and, under marginal sintering conditions, sintered densities. With adequate sintering temperature and time, the influence of ball milling on sintered densities diminishes.

Fine, $1 \mu \mathrm{m} \mathrm{W}$ powders enhance sinterability, but at short sintering times as-sintered ductilities are low and yield strengths are high. Long sintering times are required to coarsen the $\mathrm{W}$ particles in the microstructure in order to reach optimal ductility. $5 \mu \mathrm{m} \mathrm{W}$ powders lead to somewhat higher ductilities with short sintering times at $1440^{\circ} \mathrm{C}$. These conclusions, for $70 \% \mathrm{~W}$ alloys should apply to other 


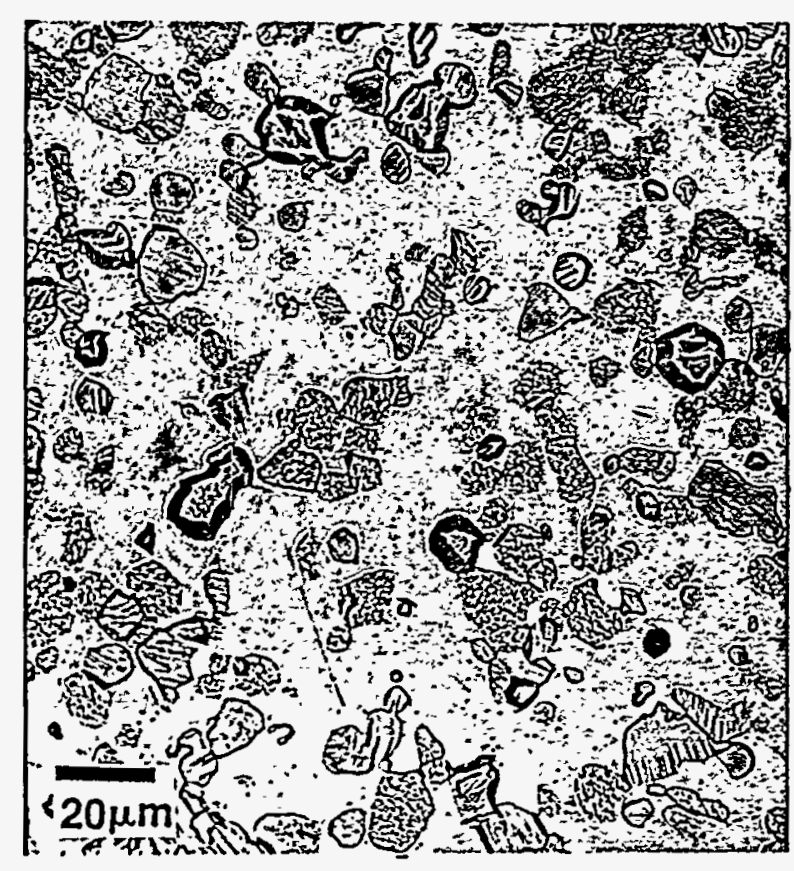

$70 \% \mathrm{~W}$

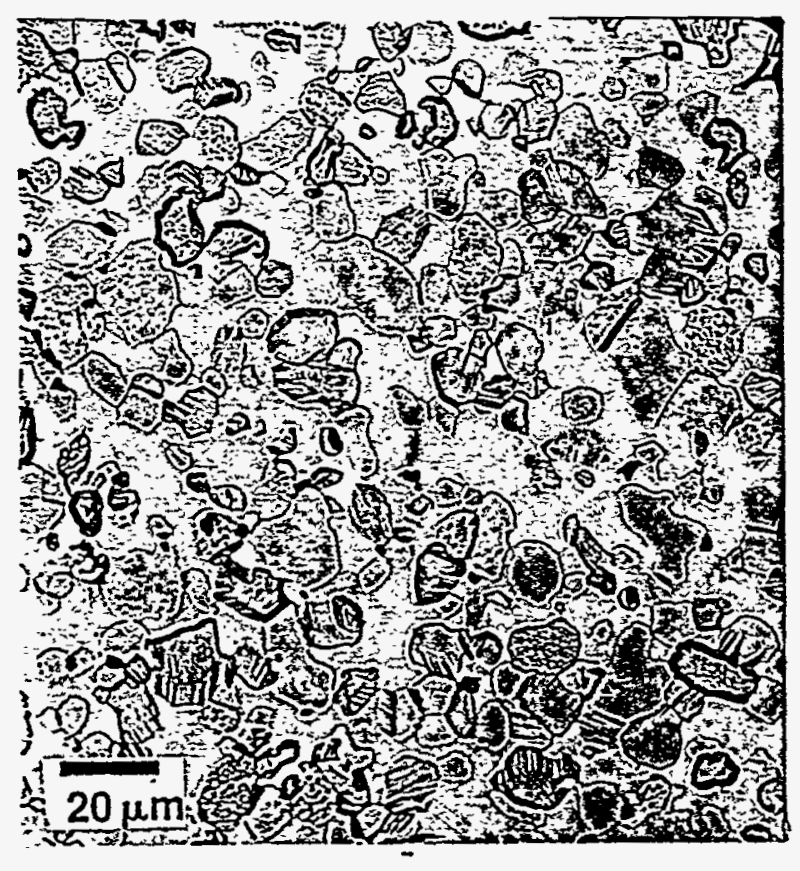

$90 \% \mathrm{~W}$

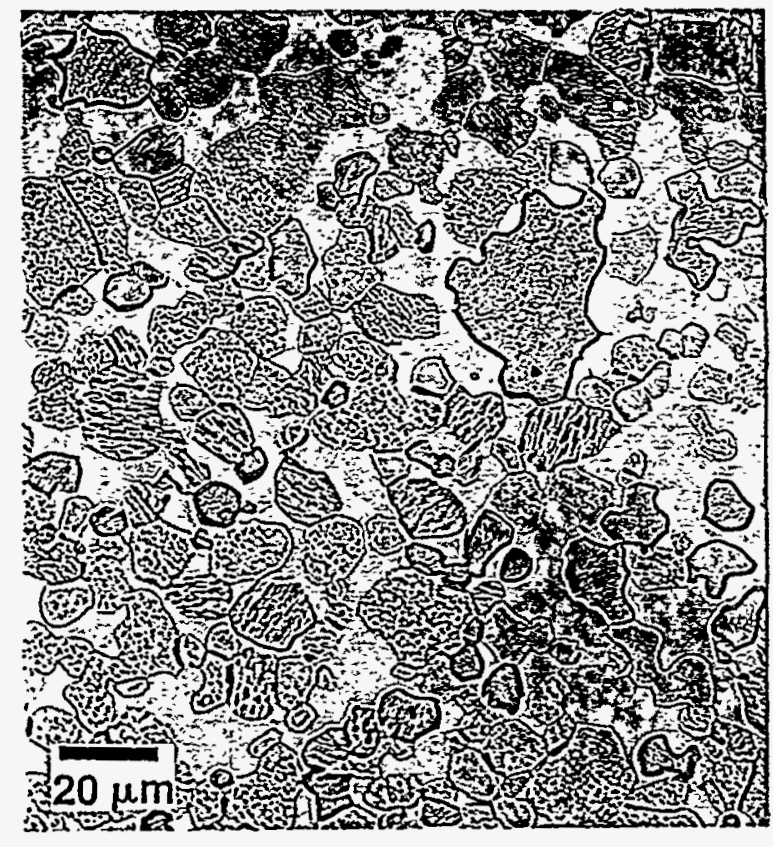

$80 \% \mathrm{~W}$

Figure 7. As-Sintered Microstructures of $70 \% \mathrm{~W}, 80 \% \mathrm{~W}$, and $90 \% \mathrm{~W}$ Alloys Made Using $10 \% 1 \mu \mathrm{m} \mathrm{W}$ Powder, Remainder $10 \mu \mathrm{m} \mathrm{W}$ Powder (8 Ni/2Fe ratio) 
$\mathrm{W}$ contents as well. Coarser, $10 \mu \mathrm{m} \mathrm{W}$ powders require the substitution of some $1 \mu \mathrm{m} W$ powder for adequate sinterability; these materials promise the highest as-sintered ductilities due to their coarse microstructural W.

\section{ACKNOWLEDGMENTS}

The following PNL staff members made significant contributions to this work: N. C. Davis, A. G. Graybeal, D. H. Parks, L. R. Shotwell, D. J. Sypolt, and G. D. White.

\section{REFERENCES}

1. W. E. Gurwell, "Heavy Metal Alloys Containing 30\% to $90 \%$ Tungsten," in Progress in Powder Metallurgy 1985, Metal Powder Industries Federation, Princeton, New Jersey, 1985, pp. 327-346.

2. W. E. Gurwell, "70\% Tungsten Heavy Alloy: Processing and Properties," in Tungsten and Tungsten Alloys: Recent Advances, The Minerals, Metals \& Materials Society, Warrendale, Pennsylvania; 1991, pp. 43-52.

3. G. D. White and W. E. Gurwell, "Freeze-Dried Tungsten Heavy Alloys," in Advances in Powder Metallurgy 1989, Metal Powder Industries Federation, Princeton, New Jersey, 1989, pp. 355-369.

4. S. Gowri and J. A. Lund, "An Alternative Diagram for Activated Sintering in W-Ni and Similar Systems," in Tungsten and Tungsten Alloys-1992, Metal Powder Industries Federation, Princeton, New Jersey, 1993a, pp. 143-154.

5. S. Gowri and J. A. Lund, "Sintering Diagrams for Tungsten Spheres and Compacts," in Tungsten and Tungsten Alloys-1992, Metal Powder Industries Federation, Princeton, New Jersey, 1993b, pp. 183-194.

6. L. L. Bourguignon and R. M. German, "Sintering Temperature Effects on a Tungsten Heavy Alloy," Int. J. Powder Metall., Vol. 24, No. 2, 1988, pp. 115-121.

7. R. M. German, Liquid Phase Sintering, Plenum Press, New York, New York, 1985.

\section{DISCLAIMER}

This report was prepared as an account of work sponsored by an agency of the United States Government. Neither the United States Government nor any agency thereof, nor any of their employees, makes any warranty, express or implied, or assumes any legal liability or responsibility for the accuracy, completeness, or usefulness of any information, apparatus, product, or process disclosed, or represents that its use would not infringe privately owned rights. Reference herein to any specific commercial product, process, or service by trade name, trademark, manufacturer, or otherwise does not necessarily constitute or imply its endorsement, recomI mendation, or favoring by the United States Government or any agency thereof. The views and opinions of authors expressed herein do not necessarily state or reflect those- of the United States Government or any agency thereof. 